\title{
OUR FIRST ORCHARD ORIOLE
}

FLOSSIE BOGDAN, Box 207, Avonlea, Saskatchewan. SOH OCO

On 26 May 1990, we heard a new bird song. We had no idea who the singer was. In the following two weeks we had many glimpses of a yellowish bird that did not fit descriptions of any of the warblers. We would say, "There's that bird again." Because of fierce winds we did not hear anymore singing until 12 June, a sunny, calm day. With binoculars, I followed the song from tree to tree and finally the singer showed himself on a somewhat bare tree branch. It was a beautiful adult male Orchard Oriole. All that afternoon, the bird flew around the yard singing.

On 13 June, I taped his song along with gusts of whistling wind, squeaky branches, and chirping young House Sparrows - on a tape recorder. Also, I wrote down what the song sounded like to me.

On the evening of 16 June, I was standing near the big window when a yellowish bird landed in a nearby tree. I had a good look at its size, wing bars and sharp bill. Then it flew down to a bush below the window and picked insects or nectar from the blossoms. With only the window between us, I stood still, watching, taking in all the details, when another of its kind came along. It too picked at the blossoms, but this new bird had a black bib. Checking with the books I identified them as female and first year male Orchard Orioles. Short phrases of song were heard on 3 and 11 July.

On 29 July, I found an empty nest woven of grasses, 11 to $12 \mathrm{ft}$. up a tree. The nest cup was about 8 in. deep. The female (before I had identified her) had been seen around the same tree.

On 26 May 1991, a year after the first sighting, I happened to be outside when I heard the now familiar song. I looked up to see a beautiful adult male Orchard Oriole, singing his heart out at the top of a tree. Unfortunately, I did not have the tape recorder handy. This time, his short visit lasted just a week. Nasty winds prevented me from taping his song.

I care to live only to entice people to look at nature's loveliness. My own special self is nothing. (I want to be) like a flake of glass through which light passes. John Muir. Cornell, 1987. Listening to Nature, Dawn Publications. 